\title{
Cocksfoot and lucerne productivity in a Pinus radiata silvopastoral system: a grazed comparison
}

\author{
P.L. PERI ${ }^{1,2}$, A.C. VARELLA ${ }^{1}$, R.J. LUCAS $^{1}$ and D.J. MOOT ${ }^{1}$ \\ ${ }^{1}$ Soil Plant and Ecological Sciences Division, PO Box 84, Lincoln University, Canterbury \\ ${ }^{2}$ Universidad Nacional de la Patagonia Austral. Convenio INTA
}

Email:lucasr@lincoln.ac.nz

\begin{abstract}
Plant and animal production from cocksfoot pasture and lucerne under 10-11 year-old radiata pine trees (200 stems/ha) and from adjacent open pastures (without trees) were measured from the Lincoln University Silvopastoral Experiment. Light intensity under trees was $50-60 \%$ of the open pasture. Liveweight gain (LWG) from lucerne was $220 \mathrm{~g} / \mathrm{hd} / \mathrm{d}$ in the open and $158 \mathrm{~g} / \mathrm{hd} / \mathrm{d}$ under trees. On cocksfoot, LWG was $132 \mathrm{~g} / \mathrm{hd} / \mathrm{d}$ in the open and $100 \mathrm{~g} / \mathrm{hd} / \mathrm{d}$ under trees. When converted to $\mathrm{LWG} /$ ha, lamb production from open pastures was double that from shaded pastures for lucerne (5.1 and $2.5 \mathrm{~kg} / \mathrm{ha} / \mathrm{d}$ ) and cocksfoot (3.4 and $1.7 \mathrm{~kg} / \mathrm{ha} /$ d). Lucerne produced $11.2 \mathrm{t} \mathrm{DM} / \mathrm{ha}$ in the open and $7.9 \mathrm{t} \mathrm{DM} / \mathrm{ha}$ under trees which was $58 \%$ and $76 \%$ more than cocksfoot in the open and under trees, respectively. However, from September to November, when soil moisture was non-limiting, the lucerne DM production was 36\% lower under tree shade than in the open. In comparison, the reduction was only $20 \%$ for cocksfoot, which confirms its greater 'shade tolerance'. The reduced lamb LWG produced from lambs on shaded pastures was attributed to the reduced pre-grazing pasture mass and pasture bulk density, leading to reduced apparent intakes. Crude protein and digestibility values were not influenced by shade, and clover content in cocksfoot pastures were low $(<7 \%)$. It was concluded that: i) shaded pastures in silvopastoral systems limited animal production compared with open pastures owing to lower DM production rates which lowered pre-grazing pasture mass and reduced bulk density from the etiolated pasture; ii) the suitability of species for silvopastoral systems should be assessed from total plant and animal production and species persistence rather than 'shade tolerance', which only examines the relative decline in DM production under shade compared with unshaded situations.
\end{abstract}

Keywords: cocksfoot, Dactylis glomerata, lamb liveweight gain, lucerne, Medicago sativa, pasture production, Pinus radiata, shade tolerance, silvopastoralism

\section{Introduction}

The general aim of agro-silvopastoral systems is to maximise profitability from a given area of land using combinations of compatible trees and crops or pastures. Silvopastoralism in New Zealand with wide spaced conifers planted in resident pasture (mainly ryegrasswhite clover pasture) has generally resulted in trees of reduced timber quality. The pasture species have been poorly adapted to tree competition (Hawke \& Knowles 1997). There is however a large area of New Zealand where trees on pastoral farms can be profitable either directly from cash returns as timber or indirectly for stock shelter and soil conservation (Mead 1995). Studies on different understorey species will indicate ways to maximise animal production from pastures under the increasing area of trees on farms.

The Lincoln University Agroforestry Experiment was established in 1990 with the aim of investigating soil/tree/pasture/sheep/climate interactions. Five Pinus radiata genotypes and six understorey pasture treatments were included in a split-plot design. After 11 years, the two pasture species which stand out are lucerne (Medicago sativa) and cocksfoot (Dactylis glomerata) and it is clear that perennial ryegrass (Lolium perenne) (infected with Neotyphodium lolii endophyte) and white clover (Trifolium repens) are unsuited to silvopastoralism in the sub-humid Canterbury plains environment.

Plant production and morphology under shade can differ between temperate grasses and legumes (Devkota et al. 1997). Research with widely spaced Pinus radiata has indicated that cocksfoot is suitable for silvopastoral systems owing to its shade tolerance (Joshi et al. 1999; Peri et al. 2001a). However, Varella et al. (2001) reported that lucerne produced more dry matter (DM) than cocksfoot under moderate shade. Furthermore, the lack of clover and presence of obvious green urine patches in cocksfoot pastures indicated that cocksfoot pastures are frequently nitrogen stressed (Peri et al. 2001a).

Foliar nitrogen concentration often increases in shaded grasses but not in shaded legumes (Wong 1990; Varella et al. 2001), while many investigations have shown variable results for herbage in vitro digestibility from shaded environments (Wilson 1989; Varella et al. 
2001). The effect of tree competition on sward characteristics, such as pasture mass, height, bulk density, reproductive development, botanical composition, and distribution of plant components within the canopy, may have an important influence on daily herbage intake and hence animal liveweight gain (Hodgson \& Brookes 1999). Also, livestock performance is reduced with increasing tree age owing to decreased light transmission. Results from the Tikitere and Waratah agroforestry trials have shown that in most cases, ewe liveweights, wool production and lamb growth rates also decreased with increasing tree stocking (Percival et al. 1984).

The objective of this research was to compare pasture and animal performance of lambs grazing lucerne and cocksfoot pastures under 10-11 year-old radiata pine and in adjacent open sites from spring 1999 to autumn 2001.

\section{Materials and methods}

\section{Experiment description}

This experiment was conducted in a silvopastoral area located near Lincoln University, Canterbury, New Zealand. The pine trees were planted in July 1990 at $1000 \mathrm{stems} / \mathrm{ha}$ and have been periodically thinned to the present 200 stems/ha with $7 \mathrm{~m}$ between rows. All thinned and pruned material has been removed from the understory pasture. Tree rows were strip sprayed (1 m wide) with herbicide (hexazinone at $2.5 \mathrm{~kg}$ a.i/ ha) to assist tree establishment. Plots with trees therefore, had only $86 \%$ of their area occupied by sown pasture. The Templeton silt loam soil consists of 1 to $2 \mathrm{~m}$ of fine alluvial sediments over gravels. The climate is temperate and subhumid with a long-term average rainfall of $660 \mathrm{~mm}$. The average annual evaporation is about double the rainfall. Mean annual temperature is $11.4^{\circ} \mathrm{C}$.

Cocksfoot ('Grasslands Wana') + clovers: 'Grasslands Pawera' red clover (Trifolium pretense) and 'Grasslands Huia' white clover (T. repens) and 'Woogenellup' subterranean (T. subterranean), and winter-dormant 'WL320' lucerne were sown in September 1990 in four $46 \times 42 \mathrm{~m}$ (0.194 ha) main plots arranged in a completely randomised block design. At the same time, three cocksfoot and lucerne plots $27.5 \times 18 \mathrm{~m}$ area were established in an adjacent open site with similar soil properties (Mead et al. 1993).

Herbage was cut and carried off the site for silage during the first 3 years but all plots were grazed by sheep from spring 1993. Neither fertiliser, lime nor irrigation has been applied to the experimental area since its establishment. Soil tests in September 1999 indicated low soil fertility with no differences between cocksfoot and lucerne plots (Open: $\mathrm{pH}$ 6.0, Olsen $\mathrm{P}$ $7.0 \mu \mathrm{g} / \mathrm{ml}, \mathrm{S}\left(\mathrm{SO}_{4}\right) 3.0 \mathrm{ppm}$; Trees: $\mathrm{pH} 5.9$, Olsen $\mathrm{P}$ $\left.7.5 \mu \mathrm{g} / \mathrm{ml}, \mathrm{S}\left(\mathrm{SO}_{4}\right) 3.5 \mathrm{ppm}\right)$.

Six new 'Grasslands Kaituna' lucerne plots were established (three in open and three under trees) in March 1999, replacing the 9-year-old phalaris (Phalaris aquatica) + clover plots. The 10-year-old "old" lucerne plots showed an average reduction of $50 \%$ in stem population compared with 1-year-old "new" lucerne in 2000. Also in 1999, three new cocksfoot plots were sown in the adjacent open site, one of these was used as the fourth plot to provide a four paddock rotation for lambs grazing cocksfoot in the open.

The current experiment ran from September 1999 to April 2001. Two flocks of shorn Coopworth ewe lambs (initial liveweight of $40 \pm 6 \mathrm{~kg}$ ) were rotationally grazed for $7 \pm 1$ days around either four cocksfoot ( 28 day rotation with $21 \pm 1$ days regrowth) or six lucerne plots (42 day rotation with $35 \pm 5$ days regrowth) under trees. Two smaller flocks of similar sheep were grazed in the same rotational pattern around cocksfoot or lucerne in the adjacent open pastures. All pastures were grazed from 15 September 1999 to 21 May 2000 (lucerne 5 May 2000) and from 21 September 2000 to 2 April 2001. The grazing in cocksfoot pasture was stopped during dry periods, from 16 March to 15 April 2000 and from 26 January to 8 March 2001, to allow pasture to accumulate a pre-grazing mass of approximately $2.0 \mathrm{t} / \mathrm{ha}$.

Stocking rate during grazing periods, over 2 years, under trees and in open, averaged $21 \mathrm{lambs} / \mathrm{ha}$ for cocksfoot and 19 lambs/ha for lucerne and was adjusted when necessary after each liveweight measurement ( $37 \pm 5$ day intervals). These adjustments resulted in similar pasture allowances for all four flocks (mean pasture allowance: $3.2 \mathrm{~kg} \mathrm{DM} / \mathrm{hd} / \mathrm{d}$ for cocksfoot and $2.8 \mathrm{~kg} \mathrm{DM} / \mathrm{hd} / \mathrm{d}$ for lucerne). Sheep parasites were controlled when necessary with anthelmintic drenches and pour-on dip.

\section{Measurements}

\section{Environmental}

Light intensity (photosynthetic photon flux density, PPFD) was monitored with quantum sensors installed below the tree canopy, but above pasture height. The level of light intensity under the 10-11-year-old trees was $60 \%$ of the open PPFD ( $100 \%$ transmittance) on a sunny day in summer and 50-55\% over a sunny day in autumn and spring. Proportions of red $(660 \mathrm{~nm})$ to farred $(730 \mathrm{~nm})$ wavelengths were measured in summer with a LI-COR spectroradiometer. The red to far-red ratio was 1.32 in the open and 0.54 under tree shade on sunny days. 
The mean volumetric soil moisture content in the top $500 \mathrm{~mm}$ was measured every 7 days with Time Domain Reflectometry (TDR) and mean daily air temperature was also recorded. In spring, soil moisture was always above $24 \%$ and was always more than half the maximum available water content of the site (mean field capacity $=30 \%$ ) indicating that the treatments were not moisture-stressed in spring. However, in both summers and autumn 2001, pastures were under water stress. Pastures under trees had $2.5 \%$ less soil moisture than open pastures owing to water extraction by tree roots. There was a small difference in mean daily temperature in the open $\left(11.8^{\circ} \mathrm{C}\right)$ and under trees $\left(12.0^{\circ} \mathrm{C}\right)$.

\section{Biological}

Pasture samples were cut prior to lambs grazing from each pasture. Pre- and post-grazing pasture masses were measured using a capacitance meter for cocksfoot pasture and by cuts in lucerne. The capacitance meter was calibrated against five dry matter cuts of both pre- and post-grazing pasture mass per treatment (open and under trees) in each 'pasture season' according to L'Huillier \& Thomson (1988). Pre-grazing canopy height was measured using a sward stick and bulk density was derived from height and pre-grazing mass. Pre-grazing botanical composition in cocksfoot pastures was determined by dissecting a sub-sample from each pre-grazing cut. Pasture and animal production per hectare under trees was calculated on the basis of plot area, but pasture variates relating to grazing behaviour were expressed on the basis of sown pasture area $(86 \%)$, to account for the sprayed area between trees.

Samples of cocksfoot and lucerne from the $0.2 \mathrm{~m}^{2}$ quadrat cuts to $25 \mathrm{~mm}$ stubble heights were analysed for crude protein (CP) and organic matter digestibility (OMD). Cocksfoot samples consisted of green tillers with $85-90 \%$ leaf and $10-15 \%$ pseudostem. Lucerne samples collected for chemical analysis consisted of $44 \%$ leaf and $56 \%$ stem both in the open and under trees.

Liveweight gain/head and grazing days were recorded, and liveweight gain/ha calculated.

\section{Statistics}

Significant $(\mathrm{p}<0.05)$ differences for pasture variables were determined by one-way analysis of variance according to the completely randomised block design. Standard deviation of means (SD) for animal variables were determined. Statistical analyses were carried out by using the Genstat statistical package (Genstat 5 1997).

\section{Results}

\section{Liveweight gains and grazing days}

Liveweight gain (LWG) per lamb was greater in open treatments than under trees (Figure 1). In both grazing years, lambs grew faster on lucerne than in cocksfoot $(189 \mathrm{vs} .115 \mathrm{~g} / \mathrm{hd} / \mathrm{d})$. The mean LWG per lamb was highest for lucerne in the open $(220 \mathrm{~g} / \mathrm{hd} / \mathrm{d})$ and under trees $(158 \mathrm{~g} / \mathrm{hd} / \mathrm{d})$ followed by cocksfoot in the open $(132 \mathrm{~g} / \mathrm{hd} / \mathrm{d})$ and under trees $(100 \mathrm{~g} / \mathrm{hd} / \mathrm{d})$ (Figure 1). The maximum LWG was in spring for animals on cocksfoot (mean of 177 in open and $127 \mathrm{~g} / \mathrm{hd} / \mathrm{d}$ under trees) and in early summer for lambs grazing lucerne ( 265 in open and $211 \mathrm{~g} / \mathrm{hd} / \mathrm{d}$ under trees).

The greater pre-grazing masses and growth rates in open plots allowed higher stocking rates than under trees and consequently more grazing days (Gd) per hectare. The mean $\mathrm{Gd} /$ ha for the grazing periods (mean of 37 days) of cocksfoot was 1004 in open and 603 under trees. For lucerne, the $\mathrm{Gd} / \mathrm{ha}$ averaged 751 in open and 572 under trees.

These treatment differences were $25 \%$ greater when grazing days were used to calculate mean daily LWG per hectare (Figure 2). This doubled in open pastures (5.1 lucerne, $3.4 \mathrm{~kg} / \mathrm{ha} / \mathrm{d}$ cocksfoot) compared with under trees (2.5 lucerne, $1.7 \mathrm{~kg} / \mathrm{ha} /$ day cocksfoot) and was greatest for cocksfoot in spring (4.5 in open and $2.9 \mathrm{~kg} / \mathrm{ha} / \mathrm{d}$ under trees) and for lucerne in spring/early summer (6.6 in open and $3.2 \mathrm{~kg} / \mathrm{ha} / \mathrm{d}$ under trees).

\section{Pasture mass and intake}

The mean annual total DM production of lucerne was 11.2 $\mathrm{t} \mathrm{DM} / \mathrm{ha}$ in open (15.2 new lucerne and $7.3 \mathrm{t} \mathrm{DM} /$ ha old lucerne) and $7.9 \mathrm{t} \mathrm{DM} / \mathrm{ha}$ under trees (9.9 new lucerne and $5.8 \mathrm{t} \mathrm{DM} /$ ha old lucerne). The mean total DM production for cocksfoot was 7.1 in open and $4.5 \mathrm{t}$ $\mathrm{DM} /$ ha under trees.

Differences in DM production resulted in the pregrazing pasture mass being greater $(p<0.05)$ in open pastures than under trees (Figure 3 ). The mean cocksfoot pasture mass on offer was $2550 \mathrm{~kg} \mathrm{DM} / \mathrm{ha}$ in the open and $1650 \mathrm{~kg} \mathrm{DM} / \mathrm{ha}$ under trees. The weighted mean pre-grazing mass for lucerne pasture was 2570 in open (3370 new lucerne and $1610 \mathrm{~kg} \mathrm{DM} / \mathrm{ha}$ old lucerne) and $1720 \mathrm{~kg} \mathrm{DM} / \mathrm{ha}$ under trees (2210 new lucerne and $1290 \mathrm{~kg} \mathrm{DM} /$ ha old lucerne).

In cocksfoot pasture, the total pre-grazing mass included obvious green urine patches covering 20$25 \%$ of the area. During spring (without water stress and temperatures non-limiting), the urine patches in open and under trees increased total DM production by $56 \%$ compared with adjacent non-urine patches and represented $35 \%$ of the total pre-grazing mass. However, in summer when soil moisture was $16-10 \%$ 
Figure 1 Liveweight gain per lamb ( $\mathrm{g} / \mathrm{hd} / \mathrm{d})$ per grazing period from cocksfoot and lucerne treatments. Arrows indicate discontinuities in grazing from September 1999 to April 2001.

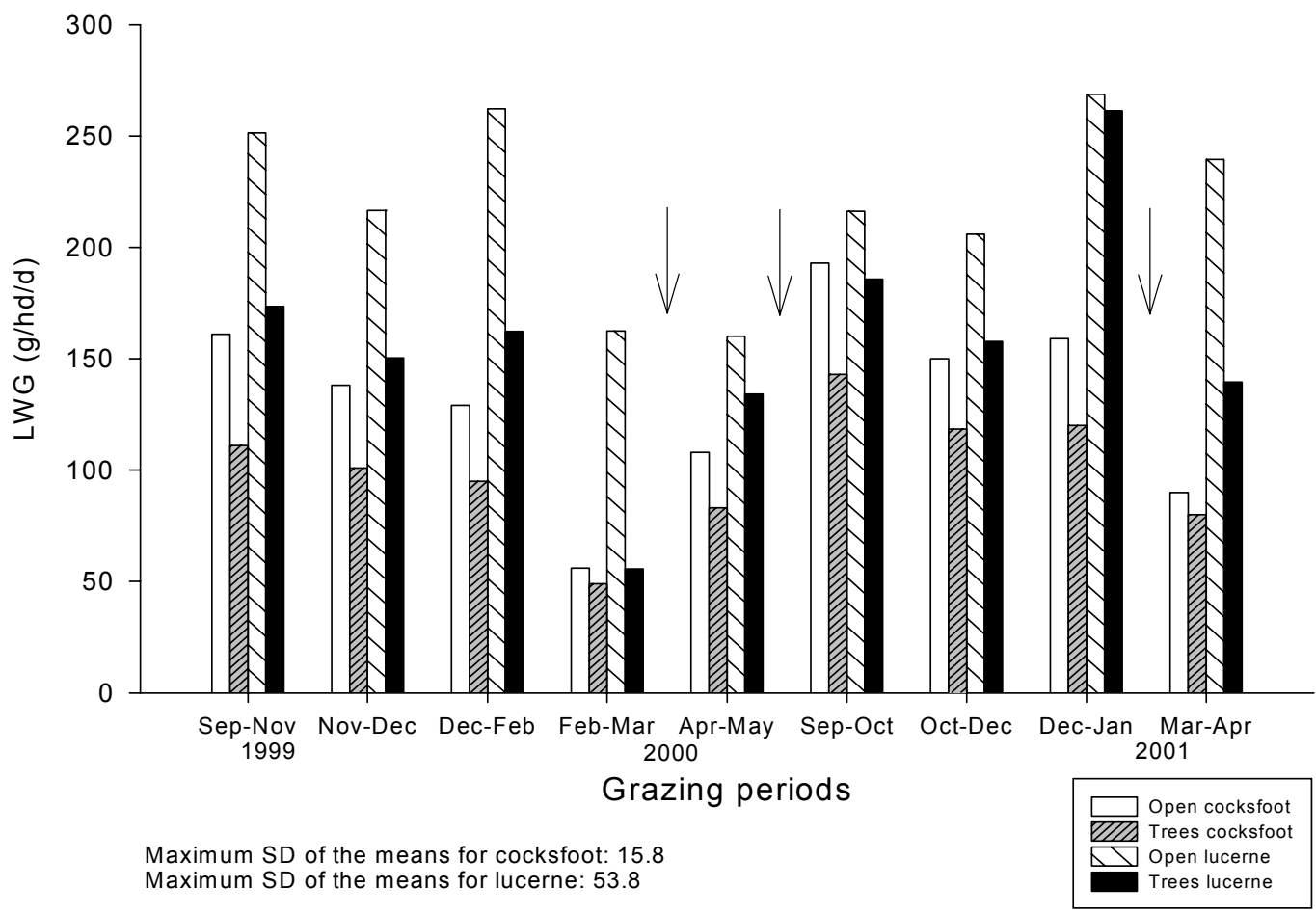

Figure 2 Liveweight gain per hectare $(\mathrm{kg} / \mathrm{ha} / \mathrm{d})$ per grazing period from cocksfoot and lucerne treatments. Arrows indicate discontinuities in grazing from September 1999 to April 2001.

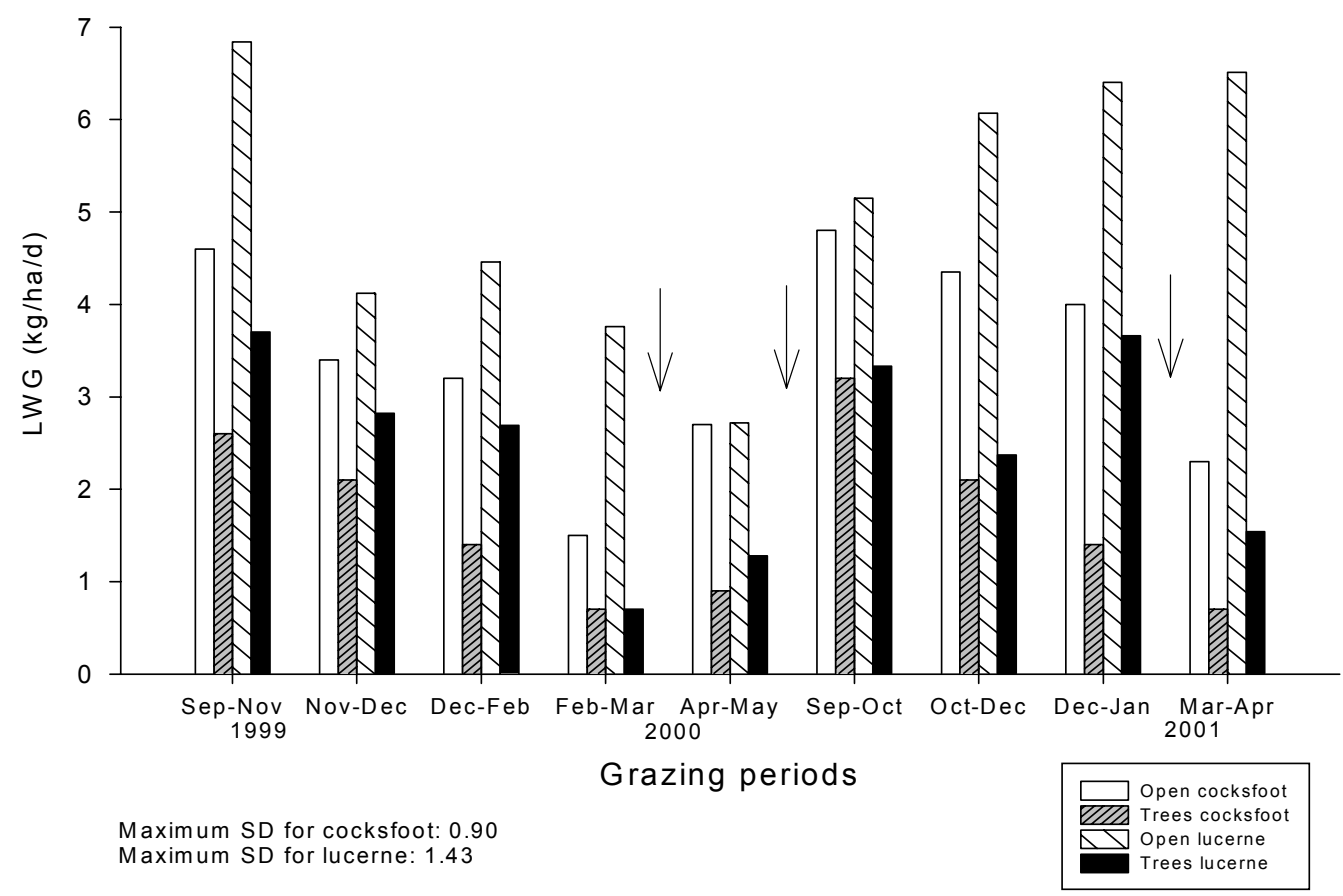


Figure $₫ 3$ Pre- $(-)$ and post-grazing $(--)$ masses $(\mathrm{kg} D M / h a)$ from cocksfoot $(\bigcirc, \boldsymbol{\bullet})$ and lucerne $(\nabla, \nabla)$ pastures, from the open $(\bigcirc, \nabla)$ and under trees $(\boldsymbol{\sigma}, \boldsymbol{\nabla})$. Data from lucerne represented the weighted mean values between new and old lucerne.
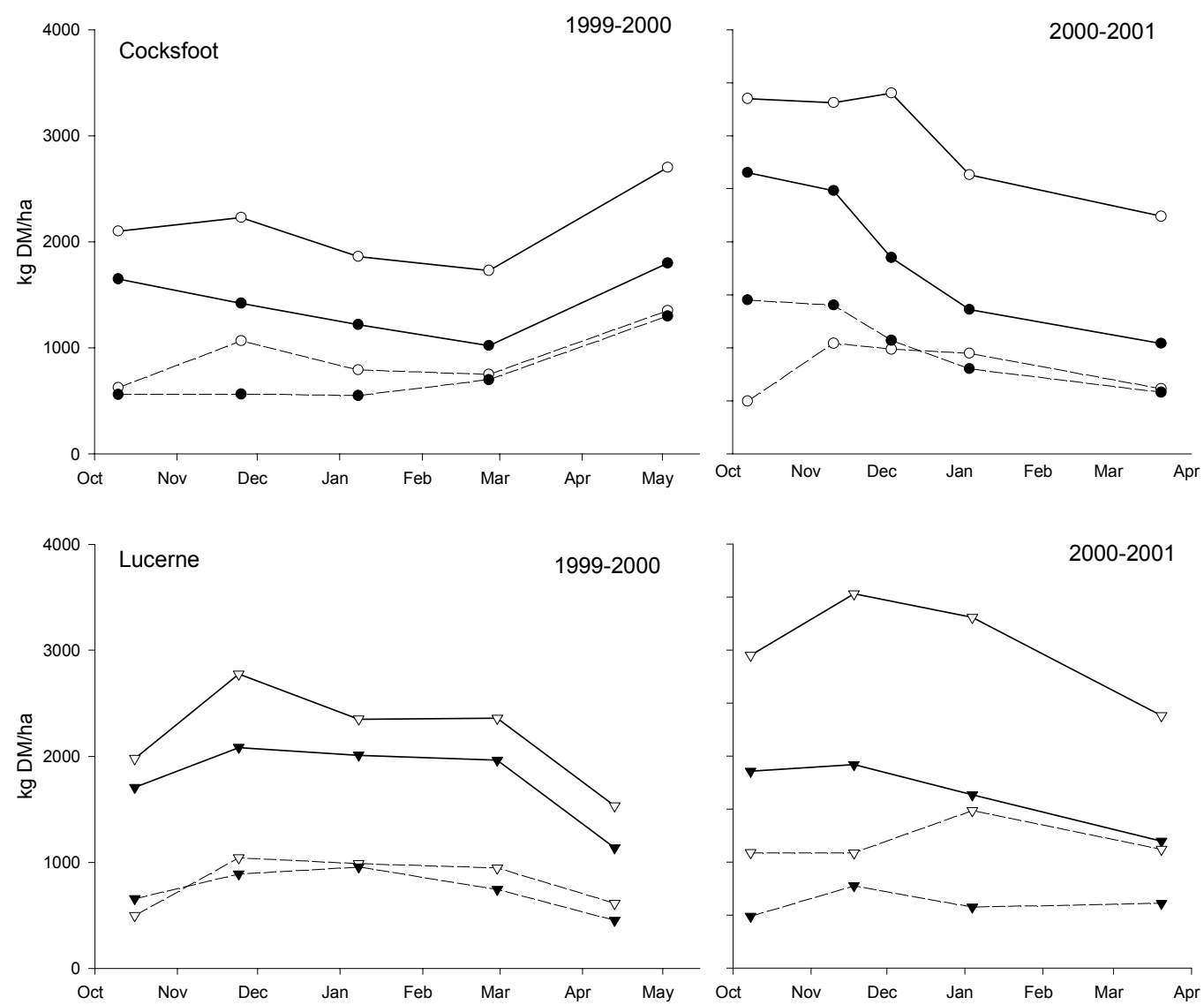

Maximum SE of the mean for cocksfoot: 340 and 260 for pre- and post-grazing masses, respectively. Maximum SE of the mean for lucerne: 280 and 330 for pre- and post-grazing masses, respectively.

Figure 44 Pre-grazing bulk density $\left(\mathrm{mg} \mathrm{DM} / \mathrm{cm}^{3}\right)$ from cocksfoot $(\bigcirc, \bigcirc)$ and lucerne $(\nabla, \boldsymbol{\nabla})$ pastures, from the open $(\bigcirc, \nabla)$ and under trees $(\boldsymbol{\nabla}, \boldsymbol{\nabla})$. Data from lucerne represented the weighted mean values between new and old lucerne.

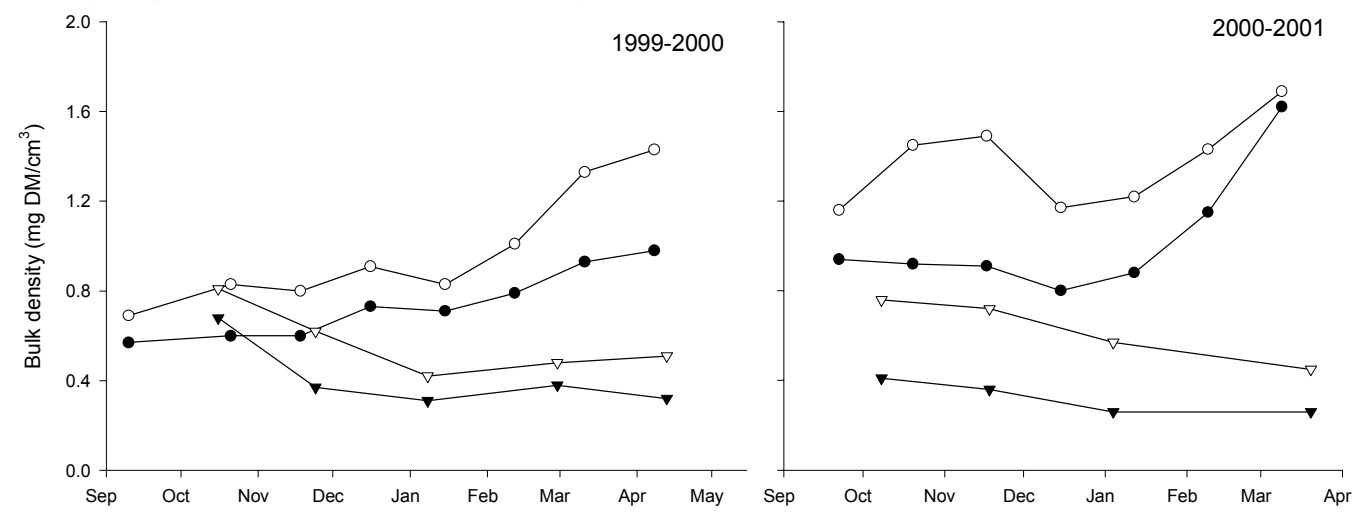

Maximum SE of the mean for cocksfoot: 0.12 and for lucerne: 0.07 . 
the urine patches increased total DM by only $5-10 \%$, and under severe water stress (soil moisture $<10 \%$ ) there was no effect of the $\mathrm{N}$ returned from sheep urine.

Post-grazing pasture mass was higher in open pastures and averaged $1270 \mathrm{~kg} \mathrm{DM} /$ ha for cocksfoot and $990 \mathrm{~kg} \mathrm{DM} / \mathrm{ha}$ for lucerne compared with $890 \mathrm{~kg}$ $\mathrm{DM} / \mathrm{ha}$ for cocksfoot and $680 \mathrm{~kg} \mathrm{DM} /$ ha for lucerne under trees. In addition, the first year cocksfoot pasture was grazed harder (mean post-grazing mass of $825 \mathrm{~kg}$ $\mathrm{DM} / \mathrm{ha}$ ) than the second year (1350 kg DM/ha).

The pre- and post-grazing masses were used to calculate the mean apparent intake which was $1.6 \mathrm{~kg}$ $\mathrm{DM} / \mathrm{hd} / \mathrm{d}$ for cocksfoot in the open and $1.3 \mathrm{~kg} \mathrm{DM} / \mathrm{hd} /$ $\mathrm{d}$ under trees. The apparent intake was $10 \%$ higher in the second grazing season compared with the first. For lucerne, the mean apparent intake was 2.1 and $1.8 \mathrm{~kg}$ $\mathrm{DM} / \mathrm{hd} / \mathrm{d}$ in open and under trees, respectively. However, the apparent intake was higher in new lucerne ( 2.4 in open and $2.1 \mathrm{~kg} \mathrm{DM} / \mathrm{hd} / \mathrm{d}$ under trees) compared with old lucerne (1.9 in open and $1.5 \mathrm{~kg} \mathrm{DM} / \mathrm{hd} / \mathrm{d}$ under trees).

\section{Pasture height, bulk density and nutritive value}

The mean lucerne height in the open was $45 \mathrm{~cm}$ compared with $49 \mathrm{~cm}$ in the shade, and $15 \mathrm{~cm}$ for cocksfoot in the open and $17 \mathrm{~cm}$ under trees cocksfoot. Bulk density was greater $(p<0.05)$ in open pastures than in those under trees, and cocksfoot had double the bulk density of lucerne (Figure 4). The mean bulk density in open pastures was $1.17 \mathrm{mg} \mathrm{DM} / \mathrm{cm}^{3}$ for cocksfoot and $0.60 \mathrm{mg} \mathrm{DM} / \mathrm{cm}^{3}$ for lucerne, and under trees it was $0.89 \mathrm{mg} \mathrm{DM} / \mathrm{cm}^{3}$ for cocksfoot and $0.37 \mathrm{mg}$ $\mathrm{DM} / \mathrm{cm}^{3}$ for lucerne. The bulk density in new lucerne ( 0.72 in open and $0.45 \mathrm{mg} \mathrm{DM} / \mathrm{cm}^{3}$ under trees) was higher than in old lucerne $(0.44$ in open and $0.30 \mathrm{mg}$ $\mathrm{DM} / \mathrm{cm}^{3}$ under trees).

The mean $\mathrm{CP} \%$ for cocksfoot plants under trees was $21.3 \%$ and $19.6 \%$ in open pastures when water was non-limiting (September-November). However, $\mathrm{CP} \%$ decreased when water stress was severe (soil moisture $<17 \%$ ). In contrast, tree shade had little effect on lucerne $\mathrm{CP} \%$ (Table 2). In general, the weighted mean $\mathrm{CP} \%$ (leaf/stem ratio) was similar between lucerne in open and under trees $(18.7 \%)$ but values for lucerne leaf $(28.1 \%)$ were more than double that of the stem $(11.8 \%)$.

Shade had little effect on both lucerne and cocksfoot OMD (Table 2) but there was a fluctuating seasonal variation. Mean OMD values for lucerne leaf and stem were 81.6 and $58.8 \%$, respectively and the weighted mean value was $68.4 \%$. Cocksfoot mean OMD was 79.3 in open pastures and $77.8 \%$ under trees.

The mean clover content of the cocksfoot pasture for the two grazing seasons was $8 \%$ in open and $4 \%$ under trees. The maximum clover content was in spring ( $14 \%$ in open vs. $6 \%$ under trees).

\section{Discussion}

\section{Animal performance}

Lamb liveweight gain (LWG) under trees was less than would be expected solely from the difference in total DM production. While annual lucerne DM production and LWG/lamb under trees were both $72 \%$ of open, the LWG/ha under trees was only $49 \%$ of that in the open lucerne (Table 1). Cocksfoot results were similar but relatively more of the reduced LWG/ ha under trees $(50 \%)$ can be explained by the reduction in pasture production $(63 \%)$ (Table 1). There is therefore an apparent reduction in pasture feeding value under trees, which is also contributing to the reduction in animal performance. Percival et al. (1984) reported that the effects of shade on sheep liveweight gain were minor at $100 \mathrm{stems} / \mathrm{ha}$, but in some years at $400 \mathrm{stems} / \mathrm{ha}$ there was a net weight loss over a 12-month period.

One of the main differences between open and shaded pastures was in pasture production rate (Varella et al. 2001). This resulted in reduced pre- and postgrazing pasture masses in shaded pastures when

Table 1 Mean total DM production, sheep liveweight gains (per hectare and per lamb), pre- and post-grazing masses, apparent intake, grazing days, pre-grazing pasture height and bulk density from cocksfoot and lucerne, in open and under trees pastures for 2 grazing years (September 1999-May 2000 and September 2000-April 2001). Mean number of days grazed per year was 180. Standard error of means (SEM) for pasture variables and standard deviation of means (SD) for animal variables are given.

\begin{tabular}{|c|c|c|c|c|c|c|c|c|c|}
\hline Treatments & $\begin{array}{c}\text { Total DM } \\
\text { (t DM/ha/yr) }\end{array}$ & $\begin{array}{l}\text { LWG/ha } \\
(\mathrm{kg} / \mathrm{d})\end{array}$ & $\begin{array}{l}\text { Pre-gazing } \\
\text { mass } \\
\text { (kg DM/ha) }\end{array}$ & $\begin{array}{l}\text { Post-gazing } \\
\text { mass } \\
(\mathrm{kg} \mathrm{DM} / \mathrm{ha})\end{array}$ & $\begin{array}{c}\text { Apparent } \\
\text { intake } \\
\text { (kg DM/hd/d) }\end{array}$ & $\begin{array}{l}\text { LWG/lamb } \\
\quad(g / d)\end{array}$ & $\begin{array}{l}\text { Grazing } \\
\text { days/ha }\end{array}$ & $\begin{array}{c}\text { Pasture } \\
\text { height }(\mathrm{cm})\end{array}$ & $\begin{array}{c}\text { Bulk } \\
\text { density } \\
\left(\mathrm{mg} \mathrm{DM} / \mathrm{cm}^{3}\right)\end{array}$ \\
\hline Open cocksfoot & 7.1 & 3.4 & 2550 & 1270 & 1.6 & 132 & 1004 & 15 & 1.17 \\
\hline Trees cocksfoot & 4.5 & 1.7 & 1650 & 890 & 1.3 & 100 & 603 & 17 & 0.89 \\
\hline$S E M-S D$ & 0.56 & 0.90 & 335.6 & 255.8 & 0.12 & 15.8 & 163.5 & 1.16 & 0.12 \\
\hline Open lucerne & 11.2 & 5.1 & 2570 & 990 & 2.1 & 220 & 751 & 45 & 0.59 \\
\hline Trees lucerne & 7.9 & 2.5 & 1720 & 680 & 1.8 & 158 & 572 & 49 & 0.37 \\
\hline SEM-SD & 0.34 & 1.43 & 280.1 & 335.4 & 0.41 & 53.8 & 195.1 & 5.54 & 0.07 \\
\hline
\end{tabular}


regrowth periods and pasture allowances were similar in open and under trees for each of the pasture types (Table 1). Apparent intakes were reduced by $0.3 \mathrm{~kg}$ $\mathrm{DM} / \mathrm{hd} / \mathrm{d}$ for lambs in both lucerne and cocksfoot flocks grazing pastures under trees (Table 1). Rattray $\&$ Clark (1984) reported that increasing pre-grazing mass per hectare resulted in increased sheep intake and liveweight gain over a range of pasture allowance.

The large reductions in shaded pre-grazing pasture masses were mainly owing to reductions in new lucerne stem (889 in open and 605 stems $/ \mathrm{m}^{2}$ under trees) and cocksfoot tiller (5400 in open and 4320 tillers/ $\mathrm{m}^{2}$ under trees) populations and their reduced individual dry weights (Peri P.L. \& Varella A.C., unpublished). Plants also responded to shade by becoming etiolated mainly owing to the decrease in red to far-red ratio. When pasture bulk densities were calculated from pre-grazing mass and plant height, density decreased to $63 \%$ of open lucerne and $76 \%$ of open cocksfoot. Grazing animals therefore had greater potential intake in open pastures than under trees. For livestock grazing lower density pasture, the amount harvestable in a single bite is smaller (Gong et al. 1996b). Reduction in bite size leads to reduced daily pasture intake and LWG because the animal normally cannot sufficiently compensate by increasing the rate of biting or grazing time per day. Alternatively, long grazing rotations could be used under trees to provide time to accumulate sufficient pasture mass. However, problems from longer spelling times would be: i) taller pasture and increased reproductive development that result in reduced bulk density, and ii) older forage of lower nutritive value.

The clover content in open cocksfoot pasture was twice that under trees in all seasons but overall clover content was low $(<7 \%)$ and consequently unlikely to have influenced animal performance.

LWG in lucerne pastures was $38 \%$ (per head) and $32 \%$ (per hectare) greater than in cocksfoot pastures (Table 1). The superior CP\% and OMD levels (mainly in leaves) and $15 \%$ greater apparent intake of lucerne contributed to this greater LWG in lucerne. However, the pasture bulk density was $52 \%$ higher in cocksfoot pastures which could have been expected to enhance pasture intake. An explanation for this apparent anomaly was provided by Gong et al. (1996a) who showed that, compared with grasses, legumes provided greater bite weights (1253 vs. $994 \mathrm{mg}$ fresh matter), faster biting rate ( 28 vs. 24 bites/min), and hence greater intake rate by sheep. Gong et al. (1996a) suggested this was because there was a higher mass bulk density within the grazed horizon in legume swards than grasses. However, they did not include lucerne in the range of species studied.
Table $₫ 2$ Mean crude protein content (CP\%) and organic matter digestibility (OMD\%) from cocksfoot and lucerne (leaf, stem and leaf/stem ratio), in open and under trees pastures for 2 grazing years (September 1999-May 2000 and September 2000-April 2001). Maximum standard deviations (Max. SD) of means are given.

\begin{tabular}{lcc}
\hline Treatments & CP (\%) & OMD (\%) \\
\hline Open cocksfoot & 17.8 & 79.3 \\
Trees cocksfoot & 18.6 & 77.8 \\
Max. SD & 0.37 & 1.89 \\
Open lucerne leaf & 28.2 & 82.2 \\
Open lucerne stem & 12.1 & 59.4 \\
Weighted mean leaf/stem ratio & 19.2 & 69.4 \\
Trees lucerne leaf & 28.1 & 81.0 \\
Trees lucerne stem & 11.6 & 58.3 \\
Weighted mean leaf/stem ratio & 18.2 & 67.4 \\
Max. SD & 3.39 & 8.55 \\
\hline
\end{tabular}

\section{Pasture production}

Cocksfoot was relatively more shade tolerant than lucerne when it was analysed during periods of nonlimiting water and temperature (SeptemberNovember). Lucerne DM production decreased 36\% under moderate tree shade (55-60\% PPFD) and cocksfoot only $20 \%$. However, when analysing the total annual DM production, results showed that lucerne produced $58 \%$ and $76 \%$ more than cocksfoot in open and under trees, respectively. The greater productivity of the light-responsive lucerne is mainly related to its deeper root system (drought tolerance), ability to fix nitrogen and the canopy structure which is efficient for capture of solar radiation.

Lucerne DM production was greater in new lucerne (2 year old) than in old lucerne plots (11-year-old). New lucerne averaged $35 \%$ and $49 \%$ more DM yield than old lucerne plots under trees and in open, respectively. Old lucerne plots had reduced plant and stem populations and patches of dense weed invasion (mainly thistles) which reduced productivity. Thus, the direct drilling of lucerne into plots under established 9 -year-old pine trees was possible and successful. Together, the productivity of "old" and "new" pastures suggests lucerne is a viable option for silvopastoral systems in this environment given that lucerne competition has beneficial effects on tree quality (Peri et al. 2001b).

\section{Nutritive value}

Cocksfoot $\mathrm{CP} \%$ increased slightly under tree shade. This may be attributed to either a decrease in photosynthates, with a consequent rise in the $\mathrm{N} \%$, or to an increase in soil organic matter mineralisation under trees that provided more nitrogen for grass uptake (Wilson et al. 1990). Lucerne CP\% changed little under 
trees compared with open. Nitrogen concentration in legumes has been reported to be similar across levels of radiation in some studies (Eriksen \& Whitney 1982) but Walgenbach \& Marten (1981) reported that lucerne had about $15 \%$ less soluble protein nitrogen under $73 \%$ shade cloth compared with full sunlight. Another reason suggested by Walgenbach \& Marten (1981) and Wilson (1989) for reduced nitrogen concentration in shaded legumes was because nodulation and symbiotic fixation were restricted by reduced carbohydrate under low illumination conditions.

There were small differences between open and shaded pastures for OMD for both cocksfoot and lucerne. Wilson (1989) reported that shading has inconsistent effects on cell wall content and composition, lignin and in vitro digestibility of plant dry matter.

After calculating the mean weighted $\mathrm{CP} \%$ and $\mathrm{OMD}$ for whole plant ( $44 \%$ leaf and 56\% stem), it was noted that lucerne nutritive value was closely associated with the stage of maturity at the harvesting date. Plants grown under trees showed a delay in development particularly in summer and early autumn. This was probably owing to lower temperatures. During this period lucerne weighted averages for $\mathrm{CP} \%$ and $\mathrm{OMD}$ were greater under trees than in open. Lucerne leaf had much higher crude protein values than cocksfoot (27 vs. $19 \mathrm{CP} \%$ ).

Although cocksfoot was more 'shade tolerant' in relative terms, lucerne DM production, feeding value and animal LWG were superior to cocksfoot under trees. The concept of 'shade tolerance' (Wong 1990) may therefore be inappropriate when screening pasture species for silvopastoral systems. More useful criteria would be the ecological stability and persistence of a pasture together with animal production per hectare. Thus, long term animal performance from a shaded pasture would provide the best indicator of its value in silvopastoral systems.

\section{Conclusions}

1. The superior sheep performance on open pastures compared with pastures under trees was attributed to the greater pasture production rate, pre-grazing mass and bulk density which allowed higher stocking rates and pasture intake.

2. Lucerne was more productive than cocksfoot in open and under Pinus radiata shade even though it was relatively more sensitive to reduced light intensity. Sheep liveweight gains (per animal and per hectare) were greater in lucerne than in cocksfoot pastures mainly owing to the superior crude protein content and apparent intakes of lucerne.
3. Cocksfoot was a persistent shade-tolerant grass which was normally nitrogen deficient because of the low white clover sward content.

\section{REFERENCES}

Devkota, N.R.; Kemp, P.D.; Hodgson, J. 1997. Screening species for shade tolerance. Proceedings of the Agronomy Society of New Zealand 27: 119127.

Eriksen, F.I.; Whitney, A.S. 1982. Growth and N fixation of some tropical forage legumes as influenced by solar radiation regimes. Agronomy Journal 74: 703-709.

Genstat 5 (1997) Genstat for windows release 3.1. Reference manual. Third edition. Lawes agricultural trust (LACAR- Rothamsted).

Gong, Y.; Hodgson, J.; Lambert, M.G.; Gordon, I.L. 1996a. Short-term ingestive behaviour of sheep and goats grazing grasses and legumes. 1. Comparison of bite weight, bite rate, and bite dimensions for forage at two stages of maturity. New Zealand Journal of Agricultural Research 39: 63-73.

Gong, Y.; Hodgson, J.; Lambert, M.G.; Gordon, I.L. 1996b. Short-term ingestive behaviour of sheep and goats grazing grasses and legumes. 2. Quantitative relationships between sets of sward and ingestive behaviour variables. New Zealand Journal of Agricultural Research 39: 75-82.

Hawke, M.F.; Knowles, R.L. 1997. Temperate agroforestry systems in New Zealand. pp. 85-118. In: Temperate agroforestry systems. Eds. Gordon, A.M.; Newman, S.M. CAB International, London.

Hodgson, J.; Brookes, I.M. 1999. Nutrition of grazing animals. In: New Zealand pasture and crop science. pp. 117-132. Eds. White, J.; Hodgson, J. Oxford University Press, Auckland.

L'Huillier, P.J.; Thomson, N.A. 1988. Estimation of herbage mass in ryegrass-white clover dairy pastures. Proceedings of the New Zealand Grassland Association 49: 117-122.

Joshi, M.R.; Lucas, R.J.; Sedcole, J.R.; Pollock, K.M.; Moot, D.J.; Mead, D.J. 1999. Shading effects of Pinus radiata on productivity and feeding value of orchardgrass pasture. Agroforestry Forum 9(3): 1719.

Mead, D.J.; Lucas, R.J.; Mason, E.G., 1993. Studying interactions between pastures and Pinus radiata in Canterbury's subhumid temperate environment the first two years. New Zealand Forestry, 26-31.

Mead, D.J. 1995. The role of agroforestry in industrialized nations: the southern hemisphere perspective with special emphasis on Australia and New Zealand. Agroforestry Systems 31: 143-156. 
Percival, N.S.; Hawke, M.F.; Bond, D.I.; Andrew, B.L. 1984. Livestock carrying capacity and performance on pasture under Pinus radiata. pp. 25-31. In: Proceedings of a Technical Workshop on Agroforestry. Ed. Bilbrough, G.W. MAF, Dunedin.

Peri, P.L.; Lucas, R.J.; Moot, D.J.; Varella, A.C.; McNeil, D.L. 2001a. Optimising yield and quality of orchardgrass pasture in temperate silvopastoral systems. In: Proceedings of the 19th International Grassland Congress 2001: 657-658.

Peri, P.L.; Mason, E.G.; Pollock, K.M.; Varella, A.C.; Mead, D.J. 2001b. Effect of understorey on early growth and quality of radiata pine stand in a silvopastoral system. Agroforestry System: In press.

Rattray, P.V.; Clark, D.A. 1984. Factors affecting the intake of pasture. New Zealand Agricultural Science 18(3): 141-146.

Varella, A.C; Peri, P.; Lucas, R.J.; Moot, D.J.; McNeil, D.L. 2001. Dry matter production and nutritive value of alfalfa (Medicago sativa L.) and orchardgrass (Dactylis glomerata L.) under different light regimes. In: Proceedings of the 19th International Grassland Congress 2001: 660-661.

Walgenbach, R.P.; Marten, G.C. 1981. Release of soluble protein and nitrogen in alfalfa. II. Influence of shading. Crop Science 21: 859-862.

Wilson, J.R. 1989. Ecophysiological constraints to production and nutritive quality of pastures under tree crops. In: Proceedings of the International Livestock-Tree Cropping Workshop. pp. 39-54. Ed. Ahmad Tajjuddin, Z. FAO, Malaysia.

Wilson, J.R.; Hill, K.; Cameron, D.M.; Shelton, H.M. 1990. The growth of Paspalum notatum under the shade of a Eucalyptus grandis plantation canopy or in full sun. Tropical Grasslands 24: 24-28.

Wong, C.C. 1990. Shade tolerance of tropical forages: a review. The environment and potential growth of herbage under plantations. pp. 64-69. In: Forages for plantation crops. Eds. Shelton, H.M.; Stur, W.W. ACIAR, Bali. 